\title{
The Effect of Altruistic Behaviors of Sports Sciences Faculty Students on the Decision of Forgiveness: A Structural Equality Model Investigation
}

\author{
Hacer Ozge Baydar Arican ${ }^{1}$ \\ ${ }^{1}$ Sport Sciences Faculty, Gazi University, Ankara, Turkey \\ Correspondence: Hacer Ozge Baydar Arican, Sport Sciences Faculty, Gazi University, 06500, Ankara, Turkey.
}

Received: October 15, 2021

Accepted: December 6, 2021

Online Published: January 19, 2022

doi:10.5539/ies.v15n1p111

URL: https://doi.org/10.5539/ies.v15n1p111

\begin{abstract}
The purpose of the present study was to examine the effects of altruism behaviors on the forgiveness decision of athletes and sedentary students who continued education in the faculty of sports sciences with the Structural Equation Model. To this end, the Study Group consisted of a total of 200 athletes and sedentary students, 108 female and 92 male, who were selected with the Convenient Sampling Method, who continued education at Gazi University Faculty of Sport Sciences. When the distribution was examined according to gender, $58.5 \%$ of the sedentary group was female and $41.5 \%$ was male. The rate of women in the athlete group was $47.6 \%$, and the rate of men was $52.4 \%$. When the distribution was examined according to age groups, the rate of people in the 17-20 group in the sedentary group was $31.4 \%$, the rate of people in the $21-24$ age group was $55.9 \%$, and the rate of people who were older than 25 was $12.7 \%$. The rate of individuals who were aged $17-20$ is $48.8 \%$ in the athlete group, the rate of individuals aged $21-24$ was $34.1 \%$, and the rate of individuals who were older than 25 years was $17.1 \%$. The "Forgiveness Decision Scale" and the "Altruism Scale" were used as measurement tools in addition to the personal information form that was created by the researcher to obtain data in the study. The Structural Equation Model and the t-test for independent groups, One-Way Analysis of Variance (ANOVA), percentage, frequency, and descriptive statistical analyzes were used in the analysis of the data. When the study findings were examined, the altruism scale sub-dimensions in the sedentary and athlete groups did not differ at significant levels according to the gender variable ( $p>0.05$ ), and the forgiveness decision scale differed at significant levels in both the athlete and sedentary groups according to gender. The level of forgiveness decision of women $(3.45 \pm 0.57)$ was higher than that of men (3.19 \pm 0.55$)$ in the sedentary group. Similarly, the level of forgiveness decision of women was higher (3.57 \pm 0.64$)$ in the athlete group than that of men $(3.41 \pm 0.61)$. When the changes of forgiveness decision scale according to age groups were examined, forgiveness in sedentary people did not differ at significant levels according to age groups ( $\mathrm{p}<0.05)$, and it did not create a significant difference according to age groups in athletes $(p<0.05)$. The Structural Equation Model was established and tested for both groups separately to determine the effect of altruism on forgiveness in sedentary and athletes. When the goodness of fit coefficients that were calculated by the Structural Equation Model was examined, both models showed a good fit. According to the Correlation Analysis that was made to determine the relations between the altruism scale and forgiveness, the scale of forgiveness was negative at $31.4 \%$ in athletes in financial aid, positive at $69.9 \%$ with help in traumatic situations, and $55.1 \%$ in help in the educational process $(\mathrm{p}<0.05)$. No significant relations were detected between forgiveness and the sub-dimensions of the altruism scale in sedentary people $(\mathrm{p}>0.05)$.
\end{abstract}

Keywords: altruistic behavior, decision to forgive, athlete, sedentary, structural equation model

\section{Introduction}

\subsection{Introduce the Problem}

When the structure of society, interpersonal communication, and interactions in our age are considered, it becomes clear that problems are inevitable. Coping with these problems and maintaining the general health status of individuals as social beings makes it important to consider the dynamics that affect the mental health of individuals more carefully. For this reason, it is very important to be able to control the situations and events causing individuals to face stress to keep the social structure, which constitutes the social dynamic. It is considered that this can be achieved by improving social relations and strengthening the positive characteristics of individuals. As a 
social phenomenon, it is critical for individuals to develop positive behaviors, improve communication skills, and maintain positive perspectives and well-being benefiting from the integrating effects of sports and sports environment. Based on this viewpoint, it is important to examine the effects of the altruistic attitudes of individuals on forgiveness decisions as a prosocial behavior, especially in athletes and sedentary individuals.

As a positive social behavior, altruism means to be important, to take into account, "for other individuals", "towards others" in Latin. It was determined that the "altruism" concept in the English literature is used as "özgecilik" in the Turkish literature. When the dictionary definition of the Turkish language institution is evaluated, an altruistic person is referred to as "a person who strives to be useful to other individuals without considering individual benefits", and altruism is expressed as "the state of being altruistic" (www.tdk.gov.tr). Batson (1991) defined altruism as a motivational situation, which adopts a strong goal to increase the welfare of other individuals. When an individual exhibits altruistic behavior, $\mathrm{s} / \mathrm{he}$ can offer what $\mathrm{s} / \mathrm{he}$ has to cover the needs of other individuals and provide benefits without any expectation as a result of this altruistic behavior. Seligman (2007) said that altruistic behaviors were considered as a gift given to the individual at the center of the behavior, which mostly pleases the other party, giving a helping hand to other people is one of the keys to happiness, an individual that has altruistic behavior moves away from personal problems, and therefore, has a different perspective. The consideration that the reinforcement of altruistic behavior will make the individual feel positive emotions more intensely and that $\mathrm{s} / \mathrm{he}$ will be more successful in individual relations has a very important place in the tendency of the individual to forgive (Diener \& Seligman, 2002).

Forgiveness is described as moving away from a negative reaction of an individual or an event that caused the resentment of an individual and the positive change in the attitudes (Thompson et al., 2005). Previous studies show that forgiveness improves the physical and mental health of individuals, increases the feeling of happiness, affects the general well-being positively, and is a tool for resolving individual conflicts (Green, Decourville, \& Sadava, 2012; Maltby, Macaskill, \& Day, 2001; Wilson, Milosevic, Carroll, Hart, \& Hibbard, 2008).

Altruistic behaviors that are exhibited without any expectations affect the subjective well-being of the individual positively, and cause that the individual feels happy (Seligman, 2007). In this respect, it is considered that an individual who exhibits altruistic behaviors may exhibit more optimistic and forgiving attitudes in social life than other individuals. For this reason, it is considered that the attempts to aid and support others voluntarily without any expectations in return may have effects on the decisions of the individual to forgive. In other words, it was stated that forgiveness is related with psychological well-being; and individuals who have good moods can maintain harmonious relations with themselves and their surroundings, develop positive perspectives in their social relations, and be more sensitive to others, especially to individuals who are in need, regardless of their individual responses (McCullough \& Witvliet, 2002; Thompson et al., 2005).

\section{Method}

Information on the study model, study group, data collection tools, data analysis, and study ethics are presented in the method section of the study.

\subsection{Study Model}

As a result of the literature review, the model of the study was determined based on the variables of the study. The Relational Screening Model was chosen from among the scientific study models in the present study. The purpose of using the Relational Screening Model in the study was to collect clues on the relations between two or more variables and cause-effect (Karasar, 2017). The Relational Screening Model was analyzed by using the Structural Equation Model. The Structural Equation Model is a combination of Factor Analysis and Regression Analysis. It is also a theoretical structure observed and represented by implicit variables (Şimşek, 2007). The hypotheses of the model that was determined in line with the purpose of the study in the relevant literature review universe are given below:

H1: Altruistic behavior affects forgiveness positively.

\subsection{Study Group}

The Study Group consisted of the athletes and sedentary students who volunteered to participate in the study and who continued their education at Gazi University Faculty of Sports Sciences. The distribution of the demographic data of the participants was examined according to the study groups. 
Table 1. The distribution of the demographic data of the participants

\begin{tabular}{cccccc}
\hline & & \multicolumn{4}{c}{ Group } \\
\cline { 3 - 6 } & & \multicolumn{3}{c}{ Sedentary } & \multicolumn{2}{c}{ Athlete } \\
\cline { 3 - 6 } & & $\mathrm{n}$ & $\%$ & $\mathrm{n}$ & $\%$ \\
\hline \multirow{2}{*}{ Gender } & Women & 69 & $58.5 \%$ & 39 & $47.6 \%$ \\
& Men & 49 & $41.5 \%$ & 43 & $52.4 \%$ \\
\hline \multirow{3}{*}{ Age Group } & $17-20$ & 37 & $31.4 \%$ & 40 & $48.8 \%$ \\
& $21-24$ & 66 & $55.9 \%$ & 28 & $34.1 \%$ \\
& $>25$ & 15 & $12.7 \%$ & 14 & $17.1 \%$ \\
\hline
\end{tabular}

When the distribution was examined according to gender, $58.5 \%$ of the sedentary group was female, and $41.5 \%$ were male students. The rate of women in the athlete group was $47.6 \%$, and the rate of men was $52.4 \%$. When the distribution was analyzed according to age groups, the rate of individuals in the 17-20 group in the sedentary group was $31.4 \%$, the rate of individuals in the $21-24$ age group was $55.9 \%$, and the rate of individuals older than 25 years was $12.7 \%$. The rate of individuals in the $17-20$ age group in the athlete group was $48.8 \%$, the rate of individuals in the 21-24 age group was $34.1 \%$, and the rate of those older than 25 years was $17.1 \%$.

\subsection{Data Collection Tools}

\subsubsection{Forgiveness Decision Scale (FDS)}

The Forgiveness Decision Scale (FDS), which was developed by Davis et al. (2015), and was adapted into Turkish by Ekşi, Parlak, and Demir Celayir (2018), consists of one single sub-dimension and 6 items in a 5-point Likert design. It is scored within the range of 1-5 points as "I Strongly Disagree" and "I Strongly Agree". The highest score obtained from the scale represents the individual's high forgiveness decision. The Cronbach Alpha value was calculated and found to be 0.91 in the reliability analysis of the scale. Item correlations for the construct validity of the scale were evaluated, and values between 0.59 and 0.84 were obtained. It was found with exploratory factor analysis that the scale consisted of one single sub-dimension and the variance was found to be $69.30 \%$. It was stated that the Turkish version of the Forgiveness Decision Scale, which was developed to determine the distinction between the forgiveness levels of individuals and their decisions to forgive, is suitable for use in scientific studies to be conducted in Turkey because it has similar values with its original form in the framework of the values obtained through analysis.

\subsubsection{Altruism Scale (AS)}

The Altruism Scale (AS), which was developed by Ümmet, Ekşi, and Otrar (2013), was validated and made reliable with a 5-point Likert design with the statements of "I Strongly Disagree", "I Do Not Agree", "I Am Indecisive", "I agree", and "I completely agree". It consists of 7 sub-dimensions and 38 items. The sub-dimensions are voluntary participation in activities, economic support, support provided in traumatic events or situations, assistance to elderly and sick people, support that requires physical strength, support for educational activities, and emotional support. When the items included in the sub-dimensions were examined, the first sub-dimension consisted of 7 items $(18,15,11,26,12,25,36)$, the second sub-dimension consisted of 6 items $(4,5,6,2,1,21)$, and the third sub-dimension consisted of 6 items $(33,23,28,30,31,34)$, the fourth sub-dimension consisted of 4 items $(10,8,20,24)$, the fifth sub-dimension consisted of items $(16,22,17,3,7)$, the sixth sub-dimension consisted of 5 items $(14,9,19,13$, and 29), and the seventh sub-dimension consisted of 5 items $(37,32,38$, 35, and 27). The Cronbach Alpha Reliability values were examined for the overall scale and its sub-dimensions, and the total Cronbach Alpha value was calculated to be .81. According to the Pearson Product-Moment Correlation Coefficient obtained to analyze any significant difference between the sub-dimensions of the scale, positive significant relations were detected between all the sub-dimensions of the scale $(\mathrm{p}<.001)$. It was also found that the sub-dimensions of the scale, which emerged as a result of scientific analyzes, expressed $51.822 \%$ of the total variance. When the internal consistency of the scale was calculated, when and the sub-dimensions and Cronbach Alpha coefficients for these dimensions were analyzed, the Cronbach Alpha value of the 1st sub-dimension was found to be .815 , 2nd sub-dimension .776, 3rd sub-dimension .757, 4th sub-dimension .760, 5th sub-dimension .743, 6th sub-dimension .696, 7th sub-dimension .659, and the total Cronbach Alpha value for the scale was calculated to be .931 .

\subsubsection{Personal Information Form}

In the personal information form that was prepared by the researcher, the age, gender, athlete, or sedentary status of the participants who were included in the study were recorded. 


\subsection{Analysis of Data}

The distribution of demographic variables, which consisted of the data of the participants, was examined with the frequency analysis according to the groups. Whether the scale scores detected in the answers given to the scale items were in line with the normal distribution was analyzed with the Kolmogorov Smirnov Test, and it was found that the data had a normal distribution. Whether the scale scores caused significant differences in the study groups according to gender and age groups was evaluated with the t-test and One-Way Analysis of Variance (ANOVA) in independent groups. The Structural Equation Model was applied to determine the effects of altruism scale sub-dimensions on forgiveness decision. The relations between the scales were evaluated with the Correlation Analysis. Analyzes were made with the SPSS 20.0 software at 95\% Confidence Interval level.

\section{Results}

The data were analyzed in this part of the study, and the findings were presented by creating tables and figures.

Table 2. The changes in altruism and forgiveness in groups according to gender

\begin{tabular}{|c|c|c|c|c|c|c|c|c|c|c|}
\hline & \multicolumn{5}{|c|}{ Sedentary } & \multicolumn{5}{|c|}{ Athlete } \\
\hline & \multicolumn{2}{|c|}{ Woman } & \multicolumn{2}{|c|}{ Men } & & \multicolumn{2}{|c|}{ Woman } & \multicolumn{2}{|c|}{ Men } & \multirow{2}{*}{$\mathrm{p}$} \\
\hline & Avg & $\mathrm{sd}$ & Avg & $\mathrm{sd}$ & & Avg & $\mathrm{sd}$ & Avg & $\mathrm{sd}$ & \\
\hline \multicolumn{11}{|l|}{ Altruism Scale } \\
\hline Participation in in voluntary activities & 2.91 & 0.55 & 2.85 & 0.59 & 0.535 & 2.77 & 0.59 & 2.90 & 0.61 & 0.323 \\
\hline Economic support & 4.11 & 0.27 & 4.10 & 0.28 & 0.797 & 4.08 & 0.27 & 4.10 & 0.24 & 0.830 \\
\hline Helping in traumatic situations & 3.86 & 0.15 & 3.90 & 0.12 & 0.085 & 3.90 & 0.15 & 3.88 & 0.11 & 0.433 \\
\hline Assistance to elderly and sick people & 4.25 & 0.23 & 4.25 & 0.23 & 0.933 & 4.24 & 0.21 & 4.25 & 0.25 & 0.901 \\
\hline Support based on physical strength & 3.41 & 0.23 & 3.48 & 0.25 & 0.113 & 3.47 & 0.26 & 3.42 & 0.25 & 0.393 \\
\hline Support for educational activities & 3.96 & 0.23 & 4.00 & 0.18 & 0.258 & 3.91 & 0.18 & 3.99 & 0.23 & 0.115 \\
\hline Emotional support & 3.42 & 0.32 & 3.33 & 0.33 & 0.124 & 3.34 & 0.28 & 3.33 & 0.31 & 0.895 \\
\hline Forgiveness decision & 3.45 & 0.57 & 3.19 & 0.55 & $0.025^{*}$ & 3.57 & 0.64 & 3.41 & 0.61 & $0.025 *$ \\
\hline
\end{tabular}

Note. $* \mathrm{p}<0.05$.

The mean values of the altruism scale sub-dimensions and the forgiveness decision scales according to the gender variable in the sedentary and athlete groups and the difference between these values were evaluated with the t-test in independent groups.

According to the t-test results in independent groups, altruism scale sub-dimensions in sedentary and athlete groups did not differ at significant levels according to the gender variable ( $p>0.05)$, and the forgiveness decision scale showed significant differences in both the athlete and sedentary groups according to the gender variable $(p<0.05)$. The level of forgiveness decision of women $(3.45 \pm 0.57)$ was found to be higher than that of men in the sedentary group (3.19 \pm 0.55$)$. Similarly, the level of forgiveness decision of women (3.57 \pm 0.64$)$ was higher in the athlete group than that of men $(3.41 \pm 0.61)$. 
Table 3. The changes in altruism and forgiveness in groups according to age groups

\begin{tabular}{|c|c|c|c|c|c|c|c|c|c|c|c|c|c|c|}
\hline & \multicolumn{7}{|c|}{ Sedentary } & \multicolumn{7}{|c|}{ Athlete } \\
\hline & \multicolumn{2}{|c|}{$17-20$} & \multicolumn{2}{|c|}{$21-24$} & \multicolumn{2}{|c|}{$>25$} & \multirow[b]{2}{*}{$P$} & \multicolumn{2}{|c|}{$17-20$} & \multicolumn{2}{|c|}{$21-24$} & \multicolumn{2}{|c|}{$>25$} & \multirow{2}{*}{$\mathrm{p}$} \\
\hline & Avg & $\mathrm{sd}$ & Avg & $\mathrm{sd}$ & Avg & sd & & Avg & $\mathrm{sd}$ & Avg & $\mathrm{sd}$ & Avg & $\mathrm{sd}$ & \\
\hline \multicolumn{15}{|l|}{ Altruism Scale } \\
\hline $\begin{array}{l}\text { Participation in voluntary } \\
\text { activities }\end{array}$ & 2.79 & 0.58 & 2.93 & 0.56 & 2.90 & 0.57 & 0.482 & 2.94 & 0.62 & 2.65 & 0.56 & 2.91 & 0.59 & 0.144 \\
\hline Economic support & 4.08 & 0.29 & 4.11 & 0.26 & 4.17 & 0.29 & 0.588 & 4.10 & 0.26 & 4.05 & 0.25 & 4.14 & 0.26 & 0.472 \\
\hline $\begin{array}{c}\text { Helping in traumatic } \\
\text { situations }\end{array}$ & 3.92 & 0.17 & 3.85 & 0.13 & 3.85 & 0.12 & $0.045^{*}$ & 3.90 & 0.12 & 3.89 & 0.13 & 3.86 & 0.16 & 0.519 \\
\hline $\begin{array}{l}\text { Assistance to elderly and } \\
\text { sick people }\end{array}$ & 4.22 & 0.30 & 4.28 & 0.20 & 4.22 & 0.13 & 0.327 & 4.28 & 0.23 & 4.22 & 0.24 & 4.21 & 0.24 & 0.563 \\
\hline $\begin{array}{l}\text { Support based on physical } \\
\text { strength }\end{array}$ & 3.49 & 0.25 & 3.40 & 0.23 & 3.45 & 0.27 & 0.173 & 3.39 & 0.24 & 3.52 & 0.23 & 3.44 & 0.30 & 0.090 \\
\hline $\begin{array}{c}\text { Support for educational } \\
\text { activities }\end{array}$ & 3.97 & 0.16 & 3.97 & 0.24 & 4.04 & 0.20 & 0.477 & 3.94 & 0.20 & 3.96 & 0.22 & 3.96 & 0.24 & 0.892 \\
\hline Emotional support & 3.31 & 0.33 & 3.43 & 0.31 & 3.33 & 0.35 & 0.144 & 3.37 & 0.31 & 3.24 & 0.28 & 3.46 & 0.24 & $0.044 *$ \\
\hline Forgiveness decision & 3.17 & 0.54 & 3.32 & 0.58 & 3.42 & 0.53 & 0.252 & 3.37 & 0.65 & 2.99 & 0.51 & 3.51 & 0.59 & $0.010 *$ \\
\hline
\end{tabular}

Note. ${ }^{*} \mathrm{p}<0.05$.

One-Way Analysis of Variance was made to determine the mean values of the altruism scale sub-dimensions and forgiveness decision scales according to the age groups in the sedentary and athlete groups, and to evaluate the significance of the difference between these values.

When the results of the One-Way Analysis of Variance are evaluated, it was found that the sub-dimension of helping in traumatic situations, which is one of the sub-dimensions of the altruism scale in sedentary people, had a significant difference according to age groups $(p<0.05)$, the sub-dimension of help them stems from the sense of proximity in athletes had a significant difference according to age ranges. When the change of the scale of forgiveness decision was examined according to age ranges, although forgiveness did not differ at significant levels in sedentary people according to age groups $(\mathrm{p}<0.05)$, it differed at significant levels according to age ranges in athletes $(\mathrm{p}<0.05)$. When the TUKEY test calculations were evaluated, which were made to find out from which group the difference stemmed from in the scales and sub-dimensions that show significant differences.

Regarding the sub-dimension of helping in traumatic situations in the sedentary group, the level of help in traumatic situations in the 17-20 age group (3.92 \pm 0.17 ) was higher at significant levels than in the 21-24 age group (3.85 \pm 0.13$)$ and in the $>25$ age group (3.85 \pm 0.12$)$.

Regarding the sub-dimension of help that stemmed from the feeling of proximity in athletes, the level of help that stemmed from the sense of proximity in the $>25$ age group (3.46 \pm 0.24$)$ was higher than in the 21-24 age group $(3.24 \pm 0.28)$ at significant levels.

Regarding the scale of forgiveness decision, the level of forgiveness decision of people who were aged $>25$ $(3.51 \pm 0.59)$ was higher than the mean score of those who were aged 21-24 (2.99 \pm 0.51$)$ and those aged 17-20 $(3.37 \pm 0.65)$ at significant levels. 
Table 4. The changes in altruism and forgiveness decision according to groups

\begin{tabular}{ccccccc} 
& \multicolumn{3}{c}{ Sedentary } & \multicolumn{2}{c}{ Athlete } & p \\
& Avg & sd & Avg & sd & \\
\hline Altruism Scale & & & & & \\
Participation in in voluntary activities & 2.256 & 0.568 & 2.835 & 0.602 & $0.047^{*}$ \\
Economic support & 4.109 & 0.273 & 4.090 & 0.254 & 0.625 \\
Support in traumatic situations & 3.476 & 0.144 & 3.889 & 0.130 & $0.013^{*}$ \\
Assistance to elderly and sick people & 4.252 & 0.230 & 4.247 & 0.231 & 0.876 \\
Support based on physical strength & 3.136 & 0.242 & 3.441 & 0.253 & $0.001^{*}$ \\
Support for educational activities & 3.978 & 0.210 & 3.951 & 0.210 & 0.377 \\
Emotional support & 3.381 & 0.326 & 3.339 & 0.294 & 0.348 \\
Forgiveness decision & 3.285 & 0.565 & 3.264 & 0.622 & 0.804 \\
\hline
\end{tabular}

Note. ${ }^{*} \mathrm{p}<0.05$.

The t-test calculations were expressed in independent groups to analyze the mean values of the altruism and forgiveness decision scale of sedentary and athletes and the significance of the difference between these values.

When the t-test analyzes are evaluated in independent groups, it was found that voluntary participation in activities, support in traumatic situations, and support based on physical strength sub-dimensions of altruism scale had significant differences in the study groups $(\mathrm{p}<0.05)$, and other sub-dimensions did not cause significant differences. The participation of athletes in voluntary activities, support in traumatic events or situations, and support based on physical strength were higher at significant levels than in sedentary ones.

\subsection{The Effects of Altruism on Forgiveness in Sedentary Individuals and Athletes}

Table 5. Model Fit Coefficients

\begin{tabular}{lcc}
\hline The coefficients of goodness of fit & Sedentary & Athlete \\
\hline$\chi^{2} / \mathrm{sd}<5$ & 4.215 & 3.741 \\
GFI $>0.90$ & 0.905 & 0.901 \\
AGFI $>0.90$ & 0.904 & 0.911 \\
CFI $>0.90$ & 0.887 & 0.909 \\
TLI $>0.90$ & 0.912 & 0.932 \\
RMSEA $<0.08$ & 0.072 & 0.071 \\
RMR $<0.08$ & 0.077 & 0.069 \\
\hline
\end{tabular}

The Structural Equation Model was used for both groups separately to determine the effect of altruism on forgiveness in sedentary and athletes. When the coefficients of goodness of fit that were calculated with the Structural Equation Model analysis were examined, it was found that both models showed a good fit.

When the model coefficients obtained for the athletes were examined, it was found that the financial aid sub-dimension affected decision to forgive at a negative and weak level (-0.33), and support in traumatic events or situations (0.78), support for the education and training process (0.59), emotional support ( 0.89$)$ had positive and high-level effects on the forgiveness decision. It was also found that other sub-dimensions did not have significant effects on forgiveness. 


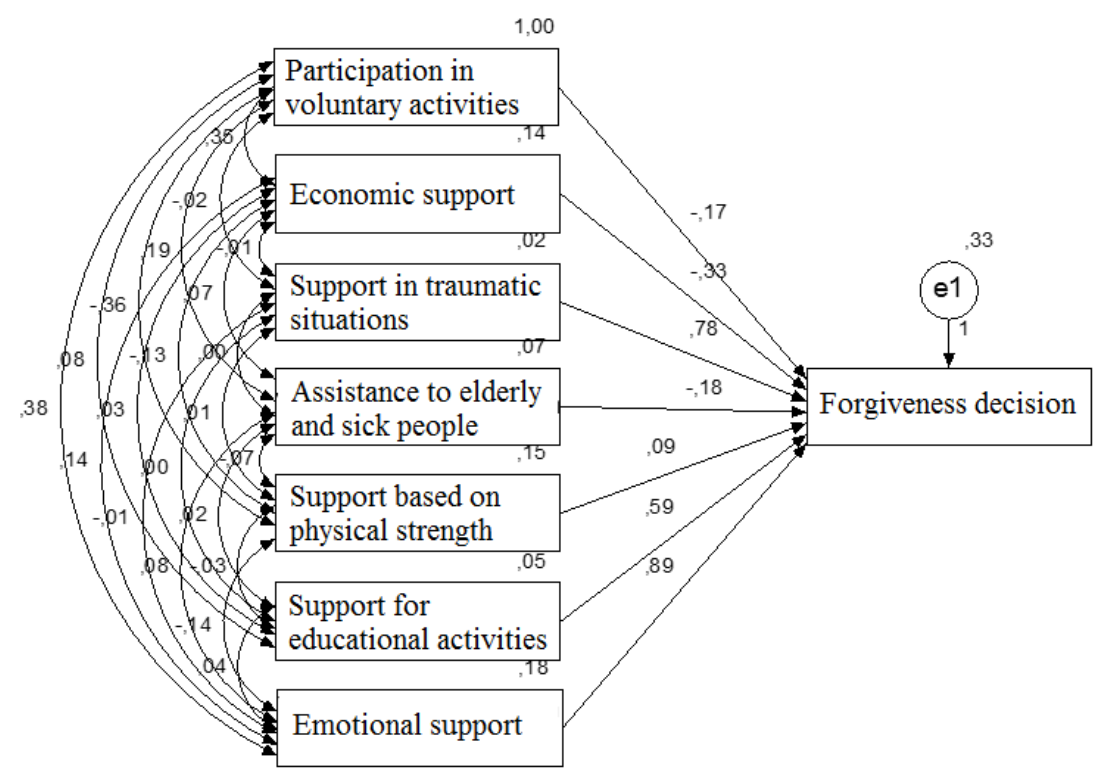

Figure 1. Model path coefficients for athletes

Aid that was based on physical strength was found to have negative and moderately significant effects on forgiveness in sedentary people, and financial assistance had a weak and significant effect on forgiveness $(-0.15)$. It was also found that other sub-dimensions did not have significant effects on forgiveness.

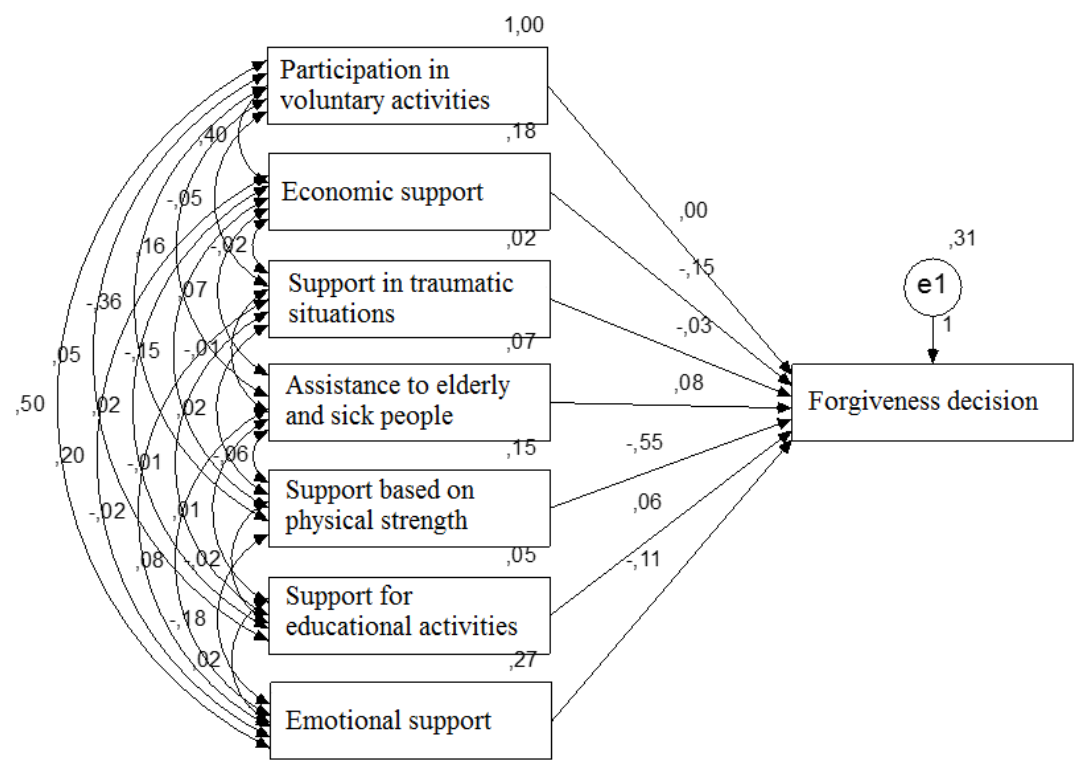

Figure 2. Model path coefficients for sedentary individuals 


\subsection{The Relation Between the Altruism Scale and the Forgiveness Decision}

Table 6. Correlation analysis results regarding altruism and decision to forgive

\begin{tabular}{lccc}
\hline & \multicolumn{3}{c}{ Decision to Forgive } \\
\cline { 2 - 4 } & & Sedentary & Athlete \\
\hline \multirow{2}{*}{ Participation in voluntary activities } & $\mathrm{r}$ & 0.113 & -0.020 \\
\cline { 2 - 4 } Economic support & $\mathrm{p}$ & 0.222 & 0.862 \\
\hline \multirow{2}{*}{ Support in traumatic situations } & $\mathrm{r}$ & 0.092 & $-0.314^{*}$ \\
\cline { 2 - 4 } & $\mathrm{p}$ & 0.322 & 0.007 \\
\hline \multirow{2}{*}{ Assistance to elderly and sick people } & $\mathrm{r}$ & -0.035 & $0.699^{*}$ \\
\hline \multirow{2}{*}{ Support based on physical strength } & $\mathrm{p}$ & 0.708 & 0.042 \\
\hline \multirow{2}{*}{ Support for educational activities } & $\mathrm{p}$ & 0.284 & 0.909 \\
\cline { 2 - 4 } & $\mathrm{p}$ & -0.158 & -0.011 \\
\hline \multirow{2}{*}{ Emotional support } & $\mathrm{p}$ & 0.087 & 0.890 \\
\cline { 2 - 4 } & $\mathrm{p}$ & 0.812 & 0.031 \\
\hline
\end{tabular}

Correlation analysis was made to evaluate the relation between the altruism scale and forgiveness, and the Pearson correlation coefficients were calculated.

According to the correlation analysis results, it was found that the scale of forgiveness was negatively correlated in athletes with financial aid at the level of $31.4 \%$, positively at the level of $69.9 \%$ with help in traumatic situations, and $55.1 \%$ with assistance in the training process $(\mathrm{p}<0.05)$. No significant relations were detected between forgiveness and the sub-dimensions of the altruism scale in sedentary people $(\mathrm{p}>0.05)$.

\section{Discussion and Conclusion}

When the results of the study were evaluated, the sub-dimensions of the altruism scale did not differ at significant levels according to the gender variable in the sedentary and athlete groups $(\mathrm{p}>0.05)$, and the forgiveness decision scale caused significant differences in both the athlete and sedentary group according to the gender variable $(\mathrm{p}<0.05)$. Supporting this finding, Baser and Kilinc (2015) reported that there were no significant differences regarding the gender variable in their study conducted to examine the altruistic behaviors of students who studied in the department of social studies teaching in terms of some variables. When the literature was reviewed, it was found that there were significant differences between the gender variable and altruism, and women were more prone to altruistic behaviors than men (Karaca, Gündüz, \& Aral, 2011; Haski-Leventhal, 2009; Rushton, Fulker, Neale, Blizard, \& Eysenck, 1984). The level of forgiveness decision of women $(3.45 \pm 0.57)$ was found to be higher in the sedentary group than that of men $(3.19 \pm 0.55)$. However, the level of forgiveness decision of women (3.57 \pm 0.64$)$ was found to be higher than that of men $(3.41 \pm 0.61)$ in the athlete group. Similarly, Çağlayan, Akandere, and Gül (2017) examined the forgiveness levels of 200 university students who did and did not do sports, and found that the average scores of women who did sports were higher than those of women who did not do sports at significant levels, and the average scores of male students who did sports were higher than those who did not do sports at significant levels. When the international literature was reviewed, studies showed that women tend to forgive more than men (Orathinkal, Vanteenwegen, \& Buruggrave, 2008; Miller, Worthington Jr., \& McDaniel, 2008). Again, when the literature data were reviewed, the studies in which the effects of the gender variable on forgiveness were evaluated were quite limited (Neto \& Mullet, 2004; Mullet, Houdbine, Laumonier, \& Girard, 1998; McCullough et al., 1998; Girard \& Mullet, 1997; McCullough, Worthington, \& Rachal, 1997). However, there are studies in the literature in which no significant relations were detected between the gender variable and forgiveness (Ayten, 2009; Gökmen, 2018; Taysi, 2007; Şahin, 2013).

Although the sub-dimension of helping in traumatic situations, which is one of the sub-dimensions of the altruism scale in sedentary people, showed significant differences according to age groups $(p<0.05)$, the sub-dimension of help that stemmed from the sense of proximity in athletes showed significant differences according to age ranges. Regarding the sub-dimension of helping in traumatic situations in the sedentary group, the level of help in traumatic situations for the 17-20 age group (3.92 \pm 0.17 ), for the $21-24$ age group ( $3.85 \pm 0.13$ ), and for the $>25$ age 
group in traumatic situations $(3.85 \pm 0.12)$ were higher at significant levels. When this finding was explained, it is considered that individuals in this age range are at the end of adolescence and therefore maintain tighter relations with the individuals around them and their friends. When the literature was reviewed, there are studies reporting that altruism behavior increases with age (Berndt, 1985; Chou, 1998). In a study that was conducted by Karadağ and Mutafçılar (2009) to examine the altruistic behaviors of teachers, it was found that social responsibility, which is one of the sub-dimensions of the altruism scale, increased in parallel with increasing age. Similarly, in another study that was conducted by Fowler (2006) to examine the relations between political orientations and altruistic behaviors, it was reported that altruistic attitude increases with age. Another finding of the study was about the sub-dimension of help that stemmed from the sense of proximity in athletes, and it was reported that the level of help stemming from the sense of proximity in the $>25$ age group (3.46 \pm 0.24$)$ was higher at significant levels than the 21-24 age group (3.24 \pm 0.28 ). It can be argued that the emergence of this finding was because of the fact that individuals gained a different perspective towards the individuals around them, apart from the individual needs in addition to the completion of their personality development as they become older. On the other hand, Ümmet (2012) examined the altruistic behaviors of university students, and reported that when the help sub-dimension scores that stemmed from the feeling of proximity were examined, individuals in the 17-19 age range had higher scores than individuals in the older age groups. Also, Malti and Dys (2018) and Brownell (2013) found in their analyzes that individuals had higher prosocial behavior levels (e.g. altruism and forgiveness) with increasing age, in other words, in post-adulthood and advanced age.

When the change in the scale of forgiveness decision was examined according to age ranges, although forgiveness did not differ at significant levels in sedentary individuals according to age groups $(p<0.05)$, it differed at significant levels according to age ranges in athletes. Regarding the scale of forgiveness decision, the level of forgiveness decision of individuals who were aged $>25$ years $(3.51 \pm 0.59)$ was higher at significant levels than the mean of individuals aged 21-24 (2.99 \pm 0.51$)$ and individuals who were aged 17-20 (3.37 \pm 0.65$)$. When this finding was explained, as individuals become older and mature in intellectual terms, they can develop different perspectives to the individuals they communicate with in social life, which may affect the tendency to forgive. Similarly, Çağlayan et al. (2017) examined the forgiveness levels of university students who did and did not do sports, and found that the levels of forgiveness of those who did sports were higher than those who did not.

When the changes in altruism behaviors and forgiveness decisions was examined according to the groups, the level of participation in voluntary activities, support and physical strength-based support in traumatic events or situations were higher than those of sedentary at significant levels. When the Structural Equation Model that was used to determine the effects of altruism behaviors on the forgiveness decisions in sedentary and athletes was evaluated, it was found that the sub-dimension of financial aid for athletes had negative and weak effects on forgiveness (-0.33) in support in traumatic events or situations (0.78), support on teaching process $(0.59)$, and emotional support (0.89). It was also found that other sub-dimensions did not have significant effects on forgiveness. However, in sedentary people, help based on physical strength had negative and moderately significant effects on forgiveness, and financial assistance had a weak (-0.15) and significant effect on forgiveness. It was also found that other sub-dimensions did not have significant effects on forgiveness. When the literature on altruism behavior and forgiveness was evaluated to explain these findings, no study was detected directly overlapping with the purpose of the study. However, it is already known that all physical activities and sports play important roles in improving the mental and physical health of individuals, strengthen the social interaction of individuals, improve the problem-solving skills, and impose different perspectives on individuals. For this reason, the positive effects of sports, exercise, and physical activities are very important for the development of altruistic behaviors and the tendency of individuals to forgive.

When this subject is evaluated from another point of view, it is known that these courses are included in the curricula to bring some social values to individuals under the name of Community Service Practices in sports sciences and educational faculties of universities. When the studies conducted on the outcomes of the Community Service Practices course were evaluated, it was observed that the students developed sensitivity in their attitudes and behaviors towards social problems, their communication skills were strengthened, they had the opportunity to think and discuss social problems, their citizenship awareness developed, and especially their social responsibility aspects developed (Gökçe, 2011; Munoz, 2003; Bilig, 2000; Waterman, 1997).

When the overall results of the study were evaluated, it was revealed that the level of forgiveness decision of women in the sedentary group was significantly higher than men according to the gender variable. Similarly, it was found that the level of forgiveness decision of women was higher in the athlete group than men. In addition, there were no significant differences in both groups according to the age variable. In other words, it was found that the related age variable did not have an effect on forgiveness decision and altruistic behavior. In this study, a structural 
equation model was created to determine the effect of altruism behavior on the decision to forgive in sedentary and athletes. According to the results obtained from the structural equation model, there was a negative relationship between the scale of forgiveness in athletes at the level of financial aid; althought having positive relationships at the level of help in traumatic situations and in the education process. On the other hand, there was no significant relationship between forgiveness decision and altruism behavior in the sedentary group.

\section{Acknowledgments}

The present study was conducted with the evaluation and approval of Gazi University Ethics Commission on 21.09.2021 with the number E-E-77082166-604.01.02-172389.

\section{References}

Ayten, A. (2009). Forgiveness and religion: an empirical research on the tendency to forgive and its relationship with religiosity (Affedicilik ve din: affetme eğilimi ve dindarlıkla ilişkisi üzerine ampirik bir araştırma). Marmara Üniversitesi İlahiyat Fakültesi Dergisi, 37(2), 111-128.

Baser, H. B., \& Kilinc, E. (2015). Investigating pre-service social studies teachers' global social responsibility level. Educational Process: International Journal, 4(1-2), 45-55. https://doi.org/10.12973/edupij.2015.412.4

Batson, C. D. (1991). The altruism question: toward a social-psychological answer. New-Jersey: Lawrence Erlbaum Associates Publishers.

Berndt, T. J. (1985). Prosocial behavior between friends in middle childhood and early adolescence. Journal of Early Adolescence, 5(3), 307-317. https://doi.org/10.1177/0272431685053005

Bilig, S. H. (2000). Research on k-12 school-based service-learning: The evidence builds. Phi Delta Kappan, 81(9), 658-664.

Brownell, C. A. (2013). Early development of prosocial behaviour: Current perspectives. Infancy, 18(1), 1-9. https://doi.org /10.1111/infa.12004

Çağlayan, H. S., Akandere, M., \& Gül, Ö. (2017). Effects of physical activities of university students' forgiveness levels (Fiziksel aktivitenin üniversite öğrencilerinin affedicilik düzeylerine etkisi). Uluslararası Ĕgitim Bilimleri Dergisi, 4(11), 314-322. https://doi.org/10.16991/INESJOURNAL.1431

Chou, K. L. (1998). Effects of age, gender, and participation in volunteer activities on the altruistic behavior of Chinese adolescents. The Journal of Genetic Psychology, 159(2), 195-201. https://doi.org/10.1080/00221329809596145

Davis, D. E., Hook, J. N., Van Tongeren, D. R., DeBlaere, C., Rice, K. G., \& Worthington, E. L., Jr. (2015). Making a decision to forgive. Journal of Counseling Psychology, 62(2), 280-288. https://doi.org/10.1037/cou0000054

Diener, E., \& Seligman, M. E. (2002). Very happy people. Psychological Science, 13(1), 81-84. https://doi.org/10.1111/1467-9280.00415

Ekşi, H., Parlak, S., \& Demir Celayir, G. (2018). Turkish adaptation of decision to forgive scale (Affetme kararı ölçeğinin Türkçe'ye uyarlanması). Proceedings of $1^{\text {st }}$ International Congress on Seeking New Perspectives in Education, 1, 25-27, Istanbul.

Fowler, J. H. (2006). Altruism and turnout. The Journal of Politics, 68(3), 674-683. https://doi.org/10.1111/j.1468-2508.2006.00453.x

Girard, M., \& Mullet, E. (1997). Propensity to forgive in adolescents, young adults, older adults, and elderly people. Journal of Adult Development, 4(4), 209-220. https://doi.org/10.1007/BF02511412

Gökçe, N. (2011). Social studies teacher candidates' opinions about the practice of community service (Sosyal bilgiler öğretmen adaylarının topluma hizmet uygulamalarına iliskin değerlendirmeleri). Uluslararası İnsan Bilimleri Dergisi, 8(2), 176-194.

Gökmen, G. (2018). Examining the factors predicting forgiveness of the university students (Üniversite ögrencilerinde affetmeyi yordayan bazı değisskenlerin incelenmesi) (Master's thesis, Akdeniz University). Acikerisim. Retrieved from http://acikerisim.akdeniz.edu.tr/xmlui/handle/123456789/4038

Green, M., Decourville, N., \& Sadava, S. (2012). Positive affect, negative affect, stress, and social support as mediators of the forgiveness-health relationship. The Journal of Social Psychology, 152(3), 288-307. https://doi.org/10.1080/00224545.2011.603767 
Haski-Leventhal, D. (2009). Altruism and volunteerism: The perceptions of altruism in four disciplines and their impact on the study of volunteerism. Journal for the Theory of Social Behaviour, 39(3), 271-299. https://doi.org/10.1111/j.1468-5914.2009.00405.x

Karaca, N. H., Gündüz, A., \& Aral, N. (2011). Examining the social behavior of preschool children (Okul öncesi dönem çocuklarının sosyal davranışının incelenmesi). Journal of Theoretical Educational Science, 4(2), 65-76.

Karadağ, E., \& Mutafçılar, I. (2009). A research on altruism levels of the primary and secondary school teachers (Illk ve ortaöğretim okulu öğretmenlerinin özgecilik düzeyleri üzerine bir araştırma). Ondokuz Mayls Üniversitesi Ĕ̈itim Fakültesi Dergisi, 28, 75-92.

Karasar, N. (2017). Scientific research method (Bilimsel araştırma yöntemi). Ankara: Nobel Yayın Dağııım.

Maltby, J., Macaskill, A., \& Day, L. (2001). Failure to forgive self and others: a replication and extension of the relationship between forgiveness, personality, social desirability and general health. Personality and Individual Differences, 30(5), 881-885. https://doi.org/10.1016/S0191-8869(00)00080-5

Malti, T., \& Dys, S. P. (2018). From being nice to being kind: Development of prosocial behaviours. Current Opinion in Psychology, 20, 45-49. https://doi.org/10.1016/j.copsyc.2017.07.036

McCullough, M. E., \& Witvliet, C. V. (2002). The psychology of forgiveness. Handbook of positive Psychology, 2, 446-455.

McCullough, M. E., Rachal, K. C., Sandage, S. J., Worthington, E. L., Wade Brown, S., \& Hight, T. L. (1998). Interpersonal forgiving in close relationships: II. Theoretical elaboration and measurement. Journal of Personality and Social Psychology, 75(6), 1586-1603. https://doi.org/10.1037/0022-3514.75.6.1586

McCullough, M. E., Worthington, E. L., \& Rachal, K. C. (1997). Interpersonal forgiving in close relationships. Journal of Personality and Social Psychology, 73(2), 321-336. https://doi.org/10.1037/0022-3514.73.2.321

Miller, A. J., Worthington Jr, E. L., \& McDaniel, M. A. (2008). Gender and forgiveness: a meta-analytic review and research agenda. Journal of Social and Clinical Psychology, 27(8), 843-876. https://doi.org/10.1521/jscp.2008.27.8.843

Mullet, E., Houdbine, A., Laumonnier, S., \& Girard, M. (1998). Forgivingness: Factorial structure in a sample of young, middle-aged, and elderly adults. European Psychologist, 3(4), 289-297. https://doi.org/10.1027/1016-9040.3.4.289

Munoz, J. S. (2003). Community resource mapping an exciting tool for decision making in the social studies classroom. Social Studies, 94(1), 20-22. https://doi.org/10.1080/00220973.1945.11019961

Neto, F. (1989). Loneliness, self-concept and social anxiety (Solitude, concept de soi et anxie'te' sociale). Cahiers d'Anthropologie et Biome'trie Humaine, 7(3-4), 173-179.

Neto, F., \& Mullet, E. (2004). Personality, self-esteem, and self-construal as correlates of forgivingness. European Journal of Personality, 18(1), 15-30. https://doi.org/10.1002/per.500

Orathinkal, J., Vanteenwegen, A., \& Buruggrave, R. (2008). Are deographics important for forgiveness?. The Family Journal, 16(20), 20-27. https://doi.org/10.1177/1066480707309542

Rushton, J. P., Fulker, D. W., Neale, M. C., Blizard, R. A., \& Eysenck, H. J. (1984). Altruism and genetics. Acta geneticae medicae et gemellologiae: Twin research, 33(2), 265-271. https://doi.org/10.1017/S0001566000007315

Şahin, M. (2013). Examining the relationship between forgivingness and psychological well-being in terms of different variables (Affedicilik ile psikolojik iyi olma arasındaki ilişkinin çeşitli değiş̧kenler açısından incelenmesi) (Master's thesis, Sakarya University). Acikerisim. Retrieved from http://hdl.handle.net/20.500.12619/74749

Seligman, M. E. P. (2007). Real happiness (Gerçek mutluluk) (Çev: S. Kunt Akbaş), Ankara: HYB Basım Yayın.

Şimşek, Ö. F. (2007). Introduction to structural equation modeling, basic principles and LISREL applications (Yapısal eşitlik modellemesine giriş, temel ilkeler ve LISREL uygulamaları). Ankara: Ekinoks Eğitim ve Danışmanlık Hizmetleri, Siyasal Basım ve Dağıtım.

Taysi, E. (2007). Forgiveness in Dyadic Relationships: The Role of Relationship Quality and Attributions (İkili ilişkilerde bağışlama: ilişsi kalitesi ve yüklemelerin rolü) (Doctoral dissertation, Ankara University). Dspace. Retrieved from http://hdl.handle.net/20.500.12575/29576 
Thompson, L. Y., Snyder, C. R., Hoffman, L., Michael, S. T., Rasmussen, H. N., Billings, L. S., ... Roberts, D. E. (2005). Dispositional forgiveness of self, others, and situations. Journal of Personality, 73(2), 313-360. https://doi.org/10.1111/j.1467-6494.2005.00311.x

Ümmet, D. (2012). Investigation of altruism behavior in university students in the context of transactional analysis ego states and life satisfaction (Üniversite ögrencilerinde özgecilik davranışının transaksiyonel analiz ego durumlarl ve yaşam doyumu bağlamında incelenmesi) (Doctoral dissertation, Marmara University). Proquest. Retrieved from http://proquest.com/docview/2524417888/proviewPDF/130C50B6C75A42C7PQ/1?accountid=11054

Ümmet, D., Ekşi, H., \& Otrar, M. (2013). The study of development of altruism scale (Özgecilik (altruism) ölçeği geliştirme çalışması). Değerler Eğitimi Dergisi, 11(26), 301-321.

Waterman, A. S. (1997). Service-Learning: Applications from the research. Mahvah, NJ: Lawrence Erlbaum Associates.

Wilson, T., Milosevic, A., Carroll, M., Hart, K., \& Hibbard, S. (2008). Physical health status in relation to self-forgiveness and other-forgiveness in health college students. Journal of Health Psychology, 13(6), 798-803. https://doi.org/10.1177/1359105308093863

\section{Copyrights}

Copyright for this article is retained by the author(s), with first publication rights granted to the journal.

This is an open-access article distributed under the terms and conditions of the Creative Commons Attribution license (http://creativecommons.org/licenses/by/4.0/). 